The Geneva Papers on Risk and Insurance, 21 (No. 78, January 1996), 114-126

\title{
The Draft Pension Funds Directive and the Financing of Pensions in the EU
}

\author{
by Karel Lannoo*
}

\section{Introduction}

The European Commission's draft pension funds directive was a prudent first step towards achieving more convergence in the structure and financing of occupational pensions in the EU. The directive would have liberalised the investment and management of pension fund assets in the EU. Despite the fact that the directive was limited in scope, the discussions that did take place and the final outcome have shown that pensions are a very delicate matter, and that the EU's interference in the field is scarcely be tolerated. The proposal was finally withdrawn, and the experience might keep the Commission from further harmonisation in this field for some time to come. One reason for their sensitivity is that pensions are closely linked with the whole institutional set-up of nation-states and one cannot intervene in this field without touching on elements of social policy, public finance and taxation, elements that are largely a national competence.

The aim of this article is firstly to discuss the structure of pension systems and their financing in Europe. A second part will examine the problems that pensions pose from a European point of view and look at the approach of the European Commission. A third part assesses the negotiations on the draft pension funds directive, and future policy priorities are discussed in a fourth part. Some general conclusions are drawn at the end.

\section{The structure and financing of pensions in the EU}

Pension systems are a difficult matter to compare on a European basis. All the countries of the European Union have set up schemes whereby pensioners are assured of a certain level of income upon their retirement. These schemes are in the first instance part of a

\footnotetext{
* Centre for European Policy Studies, Brussels. I benefitted greatly from the discussions in a CEPS working party on the subject, the report of which was drafted by Jorgen Mortensen (1993). I wish to thank A.R.N. Ratcliff, Ron Goldby and two anonymous referees for their useful comments.
} 
statutory social security system, and in a second instance, part of the voluntary contributions by the employer/employee. Both systems, however, vary widely throughout the European Union, and it is even not always evident to trace a line between social security and voluntary systems.

Two systems can broadly speaking be distinguished: the Beveridge and the Bismarck system. Under the Beveridge system, social security benefits ensure each citizen (resident) a basic income, a flat rate pension, independent of his or her profession and earnings. Citizens are free to supplement this income with occupational provisions as part of a contract with an employer or through collective bargaining. This system was put in place in Denmark, Ireland, the Netherlands and the United Kingdom. The Bismarck system assumes that people have a right to social security benefits only insofar as they acquire that right by work. The pension benefits are earnings- and profession-related, subject generally to maximum limits. This system has been followed in Germany, Belgium, France and the southern-European countries.

During the recent decades, a convergence of both systems has taken place. In the countries that followed the Beveridge system, supplementary provisions have been instituted which are income-related and/or mandatory, e.g. the SERPS (State Earnings Related Pension Scheme) in the UK, the ATP scheme in Denmark and the WAO in the Netherlands. In the countries with the Bismarck system, legal minimum means-tested benefits have been introduced.

This historical background is important for a better understanding of the commonly used «pillar» approach when comparing pension structures. Three pillars of retirement provision are distinguished:

- first pillar: the basic social security scheme, guaranteed and managed by public institutions;

- second pillar: the complementary pension scheme, linked to employment activity, also called the professional or occupational pension; and

- third pillar: the personal accumulation of provision for retirement through savings.

Overall, the financing of benefits in the first and second pillars can be done in two ways: through repartition or capitalisation. Repartition is also called 'pay-as-you-go' (PAYG) and means that current contributions of the employed are used to cover the needs of the retired population. Workers are required to contribute a number of years to be entitled to a full pension, in general between 35 and 40 years. The level of the pension is furthermore determined by the professional and salary history. In a system under capitalisation or funding, contributions of employees are capitalised in a fund, separate from the employing company, until retirement. The level of retirement benefits in a fund is in function of the scheme: it may be either defined benefit, where the retirement income depends on the years of service and/or salary (also called average salary, or final pay in case the average is based on the final years in employment), or defined contribution, where the pension varies with the return on contributions invested. In the EU, PAYG financing is used in the first pillar, both systems are in use in the second pillar, but only capitalisation is possible in the third pillar. 
A special form of the capitalisation system exists in Germany, and to a lesser extent in some other countries, in the form of the book reserve system, whereby contributions to individual occupational pension schemes contributions (second pillar) are totally invested in the company of the employee. The provisions are shown as «book reserves» on the liabilities side of the company's balance sheet. In order to assure the solvency of the pension commitments, in case of bankruptcy of the employing company, the book reserves are covered by a guarantee fund, funded by industry.

The pillar approach is useful, since it shows the different layers in the structure of pensions in the European Union. However, it also has its fundamental flaws. A «first pillar» pension can refer to something totally different in for instance the Netherlands or the UK than in France or Italy. In the former two countries, it concerns a basic pension, or almost a social minimum, which is available to all residents (subject to contribution conditions). In the latter two countries, the pension is only awarded to those who have worked and contributed to the system, thus containing elements of the first and the second pillar. It is a basic social security schene, but linked to professional contributions.

More useful is to see the development of the second pillar in function of the benefit level (replacement income) in the first pillar. Countries with a flat rate basic pension have over time developed an important second pillar, since workers, particularly the higher paid, wanted to secure an additional replacement income for their retirement. This second pillar pension is private, as part of the contract between the employer and the employee, but it has also been subject to some degree of institutionalisation, as in the Netherlands and Denmark, where it forms part of the Collective Workers' Agreements. Also countries with an average salary-linked state pension have over the last years started to develop second pillar pensions, most importantly in countries where the benefit level is low, as was for instance the case in Belgium.

When comparing gross replacement ratios in Europe - this is the income of a retired person whose earnings have been at the national average level expressed as a percentage of that average salary - the above mentioned differences in the structure of pension schemes have to be taken into account. Data from the Commission's statistical service Eurostat reveal differences ranging from $78 \%$ for Italy, $69 \%$ for France or $90 \%$ for Spain to $48 \%$ in Ireland, the Netherlands and $46 \%$ in the UK. These figures are not a true comparison of replacement ratios, but only of the ratios of statutory pension schemes. The lower the ratios, the higher the scope for second pillar pensions. The differences also correspond to the distinction between countries with flat-rate basic pensions and those with earnings-related pensions.

Table 1: Gross replacement ratios, complete career, as a percentage of the average salary in that member state (1990)

\begin{tabular}{|l|c|c|c|c|c|c|c|c|c|c|c|c|}
\cline { 2 - 12 } \multicolumn{1}{c|}{} & B & DK & D & GR & E & F & IRL & I & L & NL & P & UK \\
\hline $\begin{array}{l}\text { married with } \\
\text { dependent partner }\end{array}$ & 58 & 62 & 53 & 102 & 90 & 69 & 48 & 78 & 67 & 48 & 82 & 46 \\
\hline single & 47 & 34 & 53 & 98 & 90 & 69 & 29 & 78 & 67 & 33 & 77 & 33 \\
\hline
\end{tabular}

Source: Eurostat, (1993), Taux de Remplacement Vieillesse, Volume 1, Series 3 D. 
Pressure to develop second pillar pensions has recently also come from another source. Constraints on public spending and the ageing of the population put public pension systems under increasing strain, and entice governments to support the introduction of private pensions. Growing dependency ratios (non-active as part of active population) dilute the financial basis for pay-as-you-go financed pensions and press governments to adjust the system. Italy has recently introduced a funded second pillar pension to reduce the burden of its high level state pension, and France is also considering the introduction of funded pension plans.

The definition of the third pillar is commonly accepted. It has no institutional link, and comes on top of the provisions accumulated under the first and second pillar. The term private personal pension is also often used is this context, although in the UK context it is confusing, since in that country this term can also refer to second pillar or voluntary occupational pensions. A general overview of pension schemes in the EU is given in Table 2.

The ways of financing of pension obligations are closely related to the taxation of pensions. Employee and employers' pension contributions to funded plans are generally tax exempt*. States that have a generalised PAYG system, however, will tax contributions to funded pension plans as ordinary income. In addition, investment earnings of the pension fund may be tax exempt. Hence, the importance of the tax element in the reform of pension financing. The development of funded pension plans in countries with a predominant PAYG system stands or falls with it.

\section{The EU and pensions}

At first glance, pensions, in a European context, are foremost linked with one of the basic freedoms of the Treaty, the mobility of labour. To the extent that differences in pension schemes hinder the mobility of labour in the EU, the obstacles should be cleared by EU legislation. This has been the main focus of the work on the subject by the Commission's social affairs directorate (DG V). It has been successful with social security pensions, but not with occupational pensions, where plenty of problems still have to be tackled.

Nonetheless, to the extent that pension schemes also build up funds, two other freedoms of the Treaty play a role, the freedom of capital movements and the freedom to provide services. Pension funds should be free to move their funds within the Community, as should be the providers of pension fund services. This has been the focus of the work of the Commission's financial institutions directorate.

\subsection{Social affairs}

In the area of social affairs, the action of the European Union has taken place more on the level of coordination than harmonisation. However, 30 years of European integration has not yet led to greater convergence of member states systems. A well known international benefits consultancy noted in the introduction to its 1992 report that «even though the Treaty of Rome calls for a harmonisation of social security systems within the

\footnotetext{
*In France, there is a tax relief for contributions to the basic social security or the supplementary AGIRC/ARRCO up to a certain ceiling.
} 


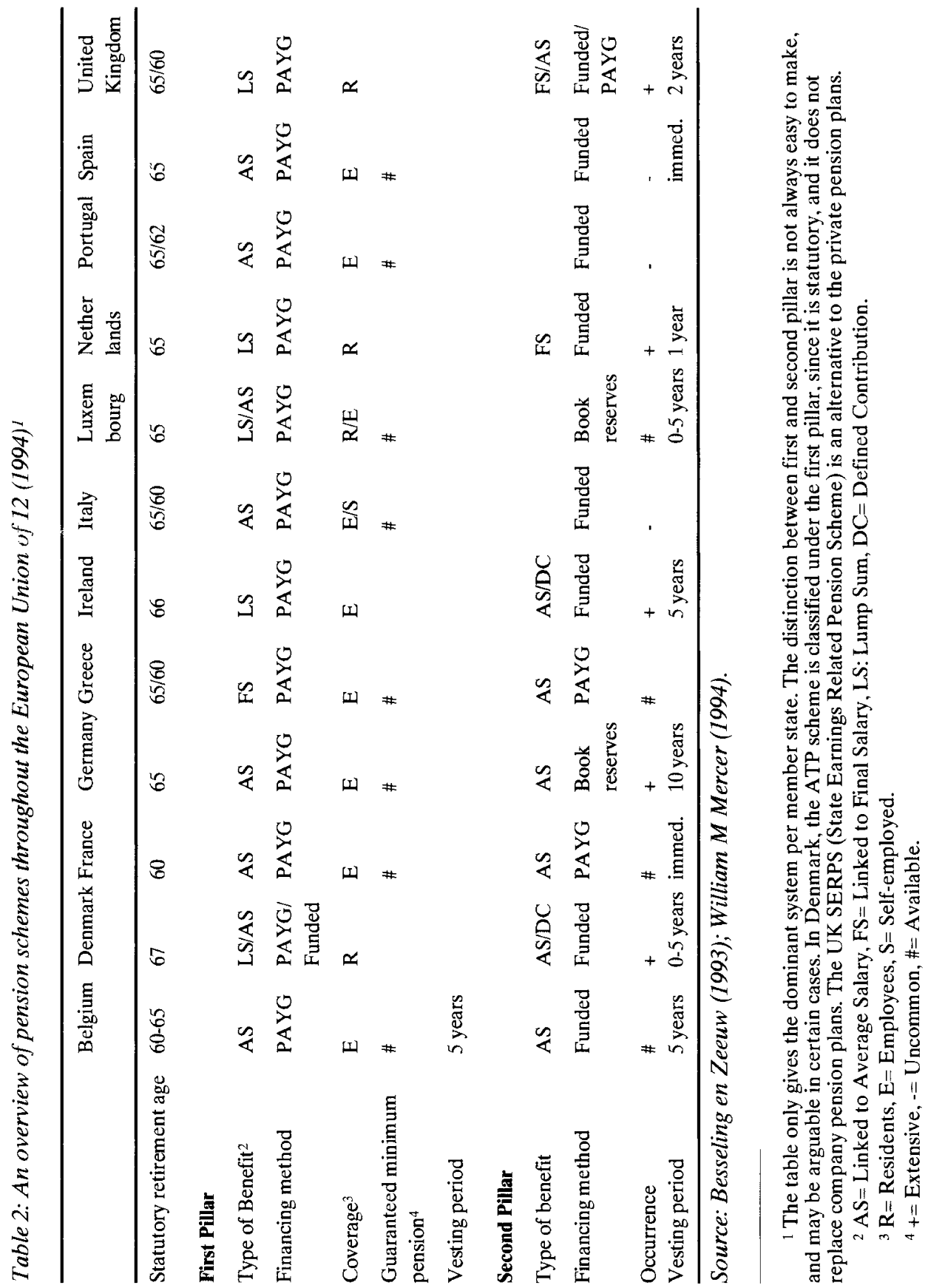


EU, there is no noticeable greater harmony among the member countries of the common market than among the other countries covered by this book». ${ }^{1}$

Two regulations of 1971 and 1972, implementing art. 51 of the Treaty, determine transferability of pension contributions to statutory social security schemes for migrating workers and pensioners. ${ }^{2}$ These historic measures set the procedures for the preservation of basic first pillar pension rights when workers move across the borders within the EU. They have made it possible for a worker to change jobs within the European Union without losing his pension rights. A worker can live in another member sate for 12 to 24 months (further extensions are negotiable), while still remaining on its national social security system. It also allows pensioners to live in another member state during their retirement and still receive their pension.

These regulations do not include occupational pension schemes. Some policy guidelines with regard to these pension plans were set out in a Commission communication in 1991. ${ }^{3}$ The Commission says in this document that the current situation of total lack of coordination between the member states of supplementary schemes is an incentive to immobility, which limits the performance of European labour markets. Steps should therefore be taken to tackle the major obstacles to mobility of workers. It considers as obstacles the acquisition of pension rights (vesting periods), its preservation and transfer, and the taxation of transfers. The document does not present immediate solutions to this problem, but suggests possible ways for more coordination. They could go in the direction of crossborder membership of pension schemes, which would be very complicated, the facilitation of the acquisition of rights and the protection of preserved rights, fair transfer options and abolishment of double taxation.

Further to this communication, a legislative proposal on the portability of occupational pensions, covering some harmonisation of pension rights, was announced in the Commission's 1995 work programme, but has already been postponed several times due to disagreements within the Commission. ${ }^{4}$ The draft would protect acquired rights in supplementary schemes and cover all migrant workers. It is however most likely that the issue will be covered in the form of a (non-legally binding) recommendation, given the small number of people involved and the complexity of the issue.

\subsection{Financial institutions}

Activity of the EU in this field is based upon the freedom of capital movements and provision of services set out in the Treaty and has been the subject of several directives so far. Funds constituted by pension schemes should be free to circulate within the Union and the institutions in charge should have the liberty to invest in the Union. Most importantly

1 International Benefits Report, The Wyatt Company, 1992

2 Regulations EEC 1408/71 and 574/72

${ }^{3}$ Supplementary social security schemes: the role of occupational pension schemes in the social protection of workers and their implications for freedom of movement, Communication from the Commission to the Council, SEC(91)1332, 22 July 1991; the document has an appendix summing up the main characteristics of supplementary pension schemes in the EC member states.

${ }_{4}^{4}$ Commission's work programme for 1995, Commission of the EC, COM(95) 26, 8.02.95. 
is the capital movements directive of $1988 . .^{5}$ This measure specifies the freedoms set out in the Treaty. It came into force in July 1990, and is also applicable in the EEA. The directive however has an article allowing member states to restrict capital movements on prudential grounds, for the sake of the protection of the general good, a clause that exists in other financial services directives as well. ${ }^{6}$

The freedom to provide services is the subject of several directives. They follow the general line of liberalisation in the financial sector which is based upon minimal harmonisation of rules, mutual recognition of supervisory systems and home country control. The directives of importance for the pension funds are the second life insurance directive, the third life insurance directive and the draft pension funds directive.

The second life insurance directive was adopted in 1990 and introduced free provision of life insurance services throughout the EU under certain conditions. ${ }^{7}$ There is free provision of services for active purchasers of life insurance, i.e. if the initiative is taken by the consumer. It also liberalised the sale of group life insurance, which covers occupational pension provisions in some member states, but management of group pension funds was not included. The directive came into force in November 1992, with transitional arrangements for Spain until end-1995, and Portugal and Greece until end-1998.

The second directive was further amended by the third life insurance directive, which came in force as from July 1994 onwards. ${ }^{8}$ This directive, proposed in early 1991, further liberalised the provision of life insurance in the EU under the sole control of the country of origin. An important difference compared with the second directive was that this directive freed the investment of assets representing the technical provisions throughout the EU, under control of the home country. It replaced national by EU localisation requirements for business written in the Community and abolished investment requirements in particular categories of assets. It set minimum rules for the investment of technical reserves, the list of admissible assets to cover these reserves, the diversification (with maximum percentages for securities, private bonds and real estate, but not for government bonds) and the valuation of investments. Transitional arrangements apply again for Spain until end-1996, and for Greece and Portugal until end-1998.

The draft pension funds directive, proposed at the end of 1991 by Sir Leon Brittan, in his capacity of Commissioner in charge of financial services, would have extended the free provision of services principles to the pension fund sector. It should have liberalised the

5 Council Directive 88/361 of 24 June 1988 for the implementation of article 67 of the Treaty, OJ L 178 of 8.7 .88 .

6 The general good clause was, for example, invoked by Spain during the October 1992 EMS crisis to temporarily restrict short term capital movements. In financial services it was already used by some member states to restrict free cross-border provision of services in mortgage lending.

${ }^{7}$ Council Directive $90 / 619$ on the Coordination of laws, regulations and administrative provisions relating to direct life assurance, laying down provisions to facilitate the effective freedom to provide services and amending directive 79/267/EEC, OJ L 330 of 29.11.1990.

${ }^{8}$ Council directive $92 / 96$ of 10 November 1992 on the coordination of laws, regulations and administrative provisions relating to life insurance and amending directives 79/267/CEE and 90/619/CEE, OJ L 360 of 9.12 .92 (third Council directive). 
investment and management of pension funds. ${ }^{9}$ In fact the directive was not only applicable to pension funds, but also to funds held by other institutions of retirement provision. All types of occupational pension institutions which are not part of the social security system would fall within its scope. As with the third life directive, the draft stipulated that member states would not be allowed to require pension funds to invest in particular categories of assets, or to localise their assets in particular member states, nor could they ask for prior approval or systematic notification requirements on investment decisions. ${ }^{10}$ But unlike the insurance directive, the draft laid down basic prudential principles which should be observed when investing pension fund assets, without minimum rules per investment instrument. Assets were to be invested in a manner appropriate to the nature and duration of the corresponding liabilities and the level of their funding, taking account of the requirements of security, quality, liquidity and profitability of the institution's portfolio as a whole. They were to be sufficiently diversified so as to avoid major accumulations of risk in the portfolio as a whole. Investments in the sponsoring firm were to be restricted to a prudent level.

The draft furthermore allowed member states, although not explicitly, to impose maximum limits of investment in particular categories, but they could not require minimum limits. They were also allowed to set rules on currency-matching: if a final pay plan was observed, up to $60 \%$ was required to be invested in domestic currency; if it concerned a money purchase or defined contribution plan, up to $80 \%$ could be required to be invested in domestic currency. Ecu-denominated assets could match any Community currency. As far as management was concerned, the draft measure allowed pension funds to seek management advice from anywhere in the Community. It stipulated that member states must not restrict the freedom of pension funds to choose an investment manager or asset custodian established in another member state.

The prudential investment rules were thus less strict in the pension funds directive than under the third life insurance directive. Insurance companies have much shorter mean term liabilities than pension funds, and can therefore be required to closely match the short term portion of their liabilities. The draft directive did furthermore not cover cross-border membership of pension funds. No mutual recognition of supervisory systems of the different member states was required. Although freedom of cross-border membership was included in an earlier draft, it was left out as it would involve much longer negotiations on minimum vesting and funding requirements, employee representation in the fund and a certain harmonisation of the taxation of pension funds. On this matter, the activity of the Commission's financial institutions directorate links up with the social affairs division.

\section{Negotiations on the draft pension funds directive}

Generally speaking, discussions on the draft pension funds directive were characterised by much ignorance on the part of member states of one another's pension systems.

${ }^{9}$ Proposal for a council directive relating to the freedom of management and investment of funds held by institutions of retirement provision, COM (91)301, OJ C 312 of 3.12.1991; amended proposal COM(93)237.

10 General investment restrictions for pension funds are in place in Belgium, Denmark, Germany, Luxembourg, Portugal and Spain. 
Although the Commission proposal resulted from the logic of the single market for financial services, it was seen by member states without significant funded pension plans as an offensive to impose a certain system. This was clearly set in a resolution of the French Assembly of 3 March 1994, presented by MP Jacques Barrot, requiring the French Government not to approve the draft, stating that «indirectly, the Commission seems with this text to determine prematurely the choice which states will make with regard to the evolution of their retirement provision structures».11 It went on by saying that it would take away the competence of national authorities in the supervision of the pension fund investments without being replaced by an equivalent Community control. The Commission proposal could only be made, it concluded, if it is integrated in a coherent convergence plan of national social systems.

The very definition of the scope of the directive (art. 2) caused substantial disagreement among member states. The directive would be applicable to «institutions for retirement provision", other than those covered by the 1971 regulation on the transferability of social security pensions, mentioned above. However, this definition proved not to be watertight, and was seen as the main reason for confusion by the British Presidency (second half of 1992), when it started the negotiations on the directive. The re-examined Commission proposal, finalised on 26 May 1993, replaced the original definition with «institution for retirement provision means an institution or a fund, other than a statutory social security body». In an annex, it provided a non-exhaustive list of statutory social security bodies that were excluded from the directive. Even this definition, however, proved not satisfactory, as governments started to add occupational pension fund bodies to this list to exclude them from the liberalising scope of the directive. The Dutch government for instance argued that ABP, the Dutch civil servants' pension fund and the same time largest European pension fund, was a statutory body, and should thus be excluded from the scope of the directive. This would only have applied temporarily, since the ABP was being privatised.

The Maxwell fraud threw some bad light on pension funds, and indirectly on the directive, although prudential supervision was not covered by the directive. The proposal did, as indicated, not include cross-border membership of pension funds, and thus not the mutual recognition of member states' supervisory systems. The directive only stated that large corporations could organise the management of their pension funds in-house on a group basis (art. 3.2). However, the European Parliament added two articles to the draft regarding the auditing of pension funds accountants and the scrutiny by its members, amendments which were not retained by the Commission. ${ }^{12}$

Also the prudent investment rules (art. 4.1) provoked disagreement between member states, again caused by differences in the structure of occupational pension schemes. Since the pension funds directive only laid down basic investment rules for pension funds, it was more liberal than the investment rules of the life insurance directives, which still set quan-

11 Proposition de Résolution sur la proposition modifiée de directive du Conseil concernant la liberté de gestion et de placement des fonds collectés par les institutions de retraite, présentée par Jacques Barrot, Deputé, Assemblée Nationale, No 1043, 3 March 1994.

12 Report of the Committee on Legal Affairs and Citizens' Rights on the draft pension funds directive, European Parliament, PE 156.259 of 9 November 1992. 
titative criteria on the diversification of insurance companies' investments. It would thereby favour pension funds over life insurance companies, which manage occupational pensions as group insurance contracts, covered by the second and third life insurance directive. The French insurers therefore rejected the proposed pension funds directive.

The article setting currency matching rules for pension funds (art. 4.3) finally caused the breakdown in the negotiations. Through this rule, member states would be allowed to require pension funds to hold up to $80 \%$ of their assets in currencies matching the liabilities. For pensions determined by the final salary, this percentage would be reduced to $60 \%$. Assets denominated in ECU would thereby be regarded as equal to any currency in the EU. However, even if these rules could be considered restrictive, certainly in the perspective of economic and monetary union, a majority of member states wanted to bring it to $80 \%$ overall. This was inspired not only by protectionist motives but also, and again, by the desire not to give pension funds more freedom than that provided by comparable rules to life insurance companies. The latter can hold no more than $20 \%$ of their assets in currencies not matching the liabilities. ${ }^{13}$

Ireland, the Netherlands and the UK - which collectively represent $82 \%$ of all pension funds assets in the EU - seemed prepared to accept the compromise of $60 \%$ matching between their own demands for no rule and the demand of the other nine states for $80 \%$. However, few of the other states were willing to compromise and the Commission was unwilling to accept a higher figure than $60 \%$, which contradicted the free movement of capital and was totally incompatible with the spirit of Economic and Monetary Union. ${ }^{14}$ Although the three member states did not form a blocking minority, unanimity would have been required in the Council to adopt a decision that opposed a Commission proposal. It finally led the Commissioner in charge, Vanni d'Archirafi, to declare on the occasion of the Internal Market Council of 16 June 1994, that the Commission envisaged withdrawing the draft directive. He said that the deadlock of the negotiations did not allow reaching an acceptable solution for the Commission and a majority of the member states, a situation that would jeopardise the coherence of the internal market for financial services. The draft directive was officially withdrawn by the European Commission on 7 December 1994 , because it had refused «to make the text acceptable to a majority of member states by inserting certain amendments which risk to completely change the sense of the directive so that instead of removing barriers to provision of services and freedom of investment, it would have legitimised such barriers», a communication stated.

The draft was replaced by a communication, which basically repeats the objectives of the draft directive, with the important difference that the measure is not legally-binding. ${ }^{15}$ The communication specifies the application of the Treaty rules on the free movement of services and capital to pension funds, and suggests that infringements will be brought before the European Court. Investment restrictions and prudential controls must be objectively justifiable: «Such rules can only be imposed if they are necessary on prudential

13 Third life insurance directive (Council directive 92/96), annex I, matching rules.

14 Internal Market Council of 16 December 1993.

15 Commission communication on the freedom of management and investment of funds held by institutions for retirement provision, Communication on an internal market for pension funds, C $360 / 08$, OJ C 360 of 17.12.94. 
grounds and are capable of justification by the general good». The communication proposes no maximum or minimum investment restrictions, and suggests an overall maximum $60 \%$ currency matching rule. The Commission has, further to this communication, sent a letter to the member states to ask them to confirm the information contained in a recent OECD report on investment restrictions on pension funds, so as to check their consistence with the Treaty and decide on further actions. However, even this communication is considered by some member states as too far-going. France has taken the European Commission to Court on the grounds that the communication went beyond the Commission's authority, since it has no right to impose a set of rules which seek to achieve the same ends as the rejected directive.

\section{Future priorities at EU level}

The European Commission also has in mind the liberalisation of cross-border membership of pension funds, because the draft pension funds directive would only have opened investment and management of pension funds to Europe-wide competition. Legislation tackling the pension problems for employees working across borders in the Union is a further objective. Although the above-mentioned 1971 regulation on social security pensions makes statutory pensions transferable, it does not apply to non-statutory occupational pensions, where considerable administrative, legal and tax barriers are in place. An employee changing jobs and employers across borders within the Union can lose his occupational pension rights, faces huge taxes on his accumulated pension rights if he wants them transferred, or loses the tax exemption benefit if he wishes to continue to pay contributions to his former pension plan.

Cross-border membership of occupational pension plans would require a minimal harmonisation of pension systems and mutual recognition. It would require member states to agree on a harmonised funding standard. This is an almost impossible objective, not only in view of the problems that emerged in the context of the discussions on the draft pension funds directive, but also because of the tax element. Pension fund contributions are exempted from taxation to different extents, and benefits from pension funds taxed as income. Harmonisation would only be attainable if it were to go to the higher end, which might not be desirable.

The Commission's DGXV had circulated a working document on the cross-border membership of occupational pension schemes for migrant workers in September 1992, proposing that mobile employees, moving within the same groupe of companies, should be able to stay in their home country scheme during a period of maximum 5 years (an extension to 10 years should be negotiable). Pension contributions to the home country scheme should be subject to the same tax treatment as is applied to contributions to equivalent host country schemes, which would in practice mean that they would be tax deductible. However, discussions on this working document have been advancing slowly, and might be even further slowed down because of the troubles with the draft pension funds directive.

Signs easing the outlook for cross-border membership of funds were nipped in the famous Bachmann Court case, but other more recent jurisprudence has provided evidence that this case resided on its own unique facts. Hans-Martin Bachmann, a German citizen living temporarily in Belgium, wanted to continue contributing to his German life insu- 
rance scheme, but could thereby not enjoy the fiscal advantages that the Belgian state offers life insurance policies with Belgium-based enterprises. He argued that this situation was contradictory to the Treaty of Rome, and especially that the conditions for deduction from income tax set by the Belgian state were contrary to art. 48,59 and 67 of the Treaty on the free movement of workers, services and capital. The Court of Justice however dismissed the application and ruled that, even if the Belgian provisions went against the Treaty, they were justified in order to guarantee the cohesion of its fiscal system. ${ }^{16}$ The Court stated that a solution was only possible through the adoption by the Council of the required coordination or harmonisation measures. In the 1995 Wielockx case on the contrary, the Court ruled that tax discrimination against non-residents in pension provisions was contrary to EC law. ${ }^{17}$

\section{Conclusions}

Several conclusions can be drawn from the debate on the draft pension funds directive:

- The draft directive was maybe a step too far. After the far-reaching liberalisation realised by the third generation insurance directives, the pension funds directive would have gone even further. It would have skipped all quantitative criteria on the spread of investments by type of instrument in favour of some basic prudential principles, to keep only some currency matching restrictions. Even if this can be justified from a theoretical point of view, this seemed have too far gone for most member states. The majority of them clearly had a different opinion of prudence in pension investments, not exclusively to favour the market for government debt. Moreover, occupational pensions organised as pension funds would have been subject to more favourable investment rules than those organised as group insurance, which would fall under the 3rd life insurance directive rules.

- Protectionism will certainly have played a role as well. Although academic papers prove that the best return of a pension fund is realised on a highly diversified portfolio, member states also wanted to assure a captive market for government bonds. Also southernEuropean countries, which are slowly setting up funded pension schemes to replace their pay-as-you-go systems, might prefer to start a solid national pension fund industry before opening their borders.

- Pensions are furthermore linked with the whole institutional set-up of nation states. Discussing pensions exclusively from the angle of free movement of services and capital is impossible, since they are foremost a social affairs and public finance issue, domains where member states' primacy prevails. Pension provision systems are hugely differing in the EU, and harmony among systems can hardly be perceived. The Commission proposal could in this respect be interpreted as favouring one system over another, as a member of the French Assembly stated. Maybe the discussion had to be conducted in a

16 European Court of Justice, Judgment of 28 January 1992, Case C-204/90, Bachmann/Belgium, Official Journal C 44 of 19.2.92.

17 European Court of Justice, Judgment of 11 August 1995, Case C-80/94, Wielockx/Inspecteur der Directe Belastingen. 
different way, in order to allow member states to first get a better understanding of one another's systems. The discussions on the definition of pension funds and the scope of the draft directive were very revealing in this respect.

Notwithstanding these remarks, it is deplorable that no agreement could be reached on the directive. Many distortions exist in the sector of occupational pensions, and the draft pension funds directive was a cautious first step. Investment restrictions may now remain in existence for pension funds in certain countries, hindering an optimal portfolio diversification. Many other problems still have to be addressed before a truly single market will come into existence in this area. Barriers that prevent employees from moving easily across borders are substantial. Not only can an employee risk the loss of his accumulated pension rights, he might also be subject to higher levels of taxation.

The withdrawal of the draft directive is in this respect a strategic mistake, as the European Commission has not only shown not to be convinced about the aims of the directive, but also about its priorities for this area. It will make it more difficult to ease cross-border membership of pension funds and tax treatment of migrating workers. The Commission should have kept the proposal in the drawer and come back on it at a more opportune moment. Moreover, referring to the European Court, as the Commission did in the communication, is a more lengthy and less secure way to defend the freedoms of the Treaty. A member state brought before Court could for example argue that pension funds should be subject to the same rules as life insurance companies, which the Court would find difficult to deny.

Failure to reach an agreement on the draft is also deplorable since more funding is needed in pension financing in Europe. Overall, member states rely heavily on pay-as-yougo schemes in the financing of pensions, and only four member states have a substantial part of their pension liabilities invested in funds. Dependency ratios are expected to double in the EU between 1990 and 2040, and with the limits on public budgets, the most relevant solution is to phase in more funding gradually. It is a pity that this common challenge has not yet led to more convergence in pension financing systems.

\section{REFERENCES}

BESSELING, P.J. and Zeeuw R.F. (1993), The financing of pensions in Europe: Challenges and opportunities, CEPS Research Report No. 14, Brussels.

DAVIS, E. P. (1993), «The development of pension funds, An approaching revolution for continental Europe», in R. O'Brien (ed.), Finance and the International Economy.

EUROSTAT (1993), Taux de Remplacement Vieillesse, Volume 1, Rapport entre revenu de retraite et revenu d'activité au moment du départ à la retraite, Series 3D.

MORTENSEN, J (1993), The financing of retirement provisions in the EC, CEPS working party report No. 9, Brussels.

THE WYATT COMPANY (1992), Benefits Report Europe, USA, Brussels.

WILLIAM M MERCER (1994), International Benefit Guidelines 1994, London. 